\title{
Regulation of Apoptosis in African Swine Fever Virus-Infected Macrophages
}

\author{
Laszlo Zsak* and John G. Neilan \\ Plum Island Animal Disease Center, USDA, ARS, P.O.Box 848, Greenport, NY 11944 \\ E-mail: Izsak@piadc.ars.usda.gov; ineilan@piadc.ars.usda.gov
}

Received February 13, 2002; Revised March 10, 2002; Accepted March 14, 2002; Published May 3, 2002

\begin{abstract}
A number of viruses have evolved antiapoptotic mechanisms to promote infectedcell survival, either to ensure efficient productive viral replication or to promote long-term survival of virus-infected cells. Recent studies identified critical African swine fever virus genes involved in the complex regulation of ASFV-host interactions. Here we review the present knowledge of the recently identified ASFV genes with special attention to those which affect viral virulence, host range, and pathogenesis by regulating viral-induced apoptotic mechanisms.
\end{abstract}

KEY WORDS: African swine fever, virus, gene, protein, macrophage, cell death, apoptosis, virulence, host range, pathogenesis, immunology

DOMAINS: gene expression, cell death, virology, genetic engineering, cell biology, infection, immunology

\section{INTRODUCTION}

African swine fever (ASF) is a highly lethal, hemorrhagic disease of domestic pigs for which there is no vaccine or disease control other than animal slaughter and area quarantine. African swine fever virus (ASFV), the causative agent of ASF, is a large, enveloped, double-stranded DNA virus which is the sole member of the newly named Asfarviridae family[1]. Although the icosahedral morphology of the ASFV virion resembles those of iridoviruses, both the genomic organization, which includes terminal cross-links and inverted terminal repeats, and its cytoplasmic replication strategy suggest some relationship with the Poxviridae family[2,3,4]. ASFV is the only known DNA arbovirus[5]. Perpetuation and transmission of this virus in nature involves the cycling of virus between two highly adapted hosts, Ornithodoros ticks and wild pig populations (warthogs and bushpigs) in sub-Saharan Africa[6]. In enzootic areas, ASFV is maintained in a sylvatic cycle between warthogs, bushpigs, and O. porcinus porcinus ticks. In the warthog host, ASFV infection is subclinical, characterized by low viremia titers[7] and reduced lymphocyte apoptosis when compared to domestic swine[8,9]. 
In domestic pigs, ASF occurs in several disease forms, ranging from highly lethal to subclinical infections, depending on contributing viral and host factors[10]. ASFV infects cells of the mononuclear-phagocytic system, including fixed tissue macrophages, and specific lineages of reticular cells in spleen, lymph node, lung, kidney, and liver[10]. This ability to replicate and induce marked cytopathology in these cell types in vivo appears to be critical for ASFV virulence. Recent studies show that pathogenic ASFV isolates can also infect primary cultures of porcine endothelial cells in vitro, suggesting that vascular endothelial cells may play important role in the pathogenesis of the disease in vivo[11].Viral and host factors responsible for the differing outcomes of infection with highly virulent strains and strains of lesser virulence are largely unknown.

ASFV is genetically complex. Its genome of 170 to $190 \mathrm{kbp}$ encodes 160 or more open reading frames (ORFs), and approximately 100 proteins have been observed in virus-infected cells[5]. Sequencing and genome analysis of the complete viral genome have led to the prediction and/or identification of genes encoding virion structural proteins and other proteins with functions involving viral virulence and/or host range, RNA transcription and modification, nucleotide metabolism, DNA replication, and protein processing[12,13, Z. Lu et al., unpublished data).

In this review, we give emphasis to the recently identified ASFV genes (see Table 1) involved in critical virus-cell interactions, specifically in the regulation of apoptosis in virusinfected target cells.

\section{ASFV GENES AFFECTING VIRULENCE, PATHOGENESIS, AND IMMUNE RESPONSE}

Early interactions between the virus and specific cellular receptors appear to be essential for a productive infection. Specific binding and internalization of ASFV to macrophages are mediated by structural viral proteins $\mathrm{p} 30, \mathrm{p} 54$, and $\mathrm{p} 12[15,18]$. While virus-specific cell receptors are necessary to confer cell susceptibility to ASFV, they are not sufficient in subsequent efficient replication, suggesting that additional virus-host interactions are significant for host range specificity[38].

Several ASFV genes are associated with pathogenesis and virulence in swine. An ASFV gene, NL, with similarity to the neurovirulence gene ICP34.5 of herpes simplex virus[39], and another terminal variable region gene, UK, were identified with functions involving virulence and host range in the pathogenic European isolate, E70[19,20]. Deletion of either NL or UK from pathogenic ASFV isolate does not affect viral growth in swine macrophage cell cultures, but markedly reduces virulence of the virus in swine. While these genes are important for ASFV virulence, they alone are not sufficient, indicating that other viral determinants must play significant roles in determining host range and viral virulence[19,20,40].

ASFV, like other large DNA viruses such as pox-, herpes-, and adenoviruses, encode nonessential, virulence-associated genes which play significant roles in downregulation of host cytokine-modulated immunological and inflammatory responses[41]. Downregulation of proinflammatory cytokine gene expression (TNF- $\alpha$ and INF- $\alpha$ ) has been observed in mitogen or phorbol myristic acid-activated porcine macrophages within $4 \mathrm{~h}$ of ASFV infection[27]. Expression of these cytokines is in part regulated by the transcription factor, nuclear factor kappa beta $(\mathrm{NF} \kappa \mathrm{B})$ protein complex. An African swine fever virus gene with similarity to the inhibitor

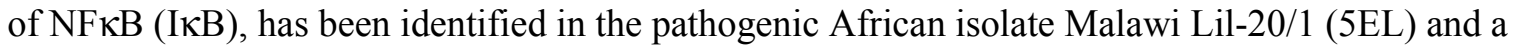
cell-culture-adapted European virus BA71V (A238L)[13,26]. Expression of A238L in pig kidney

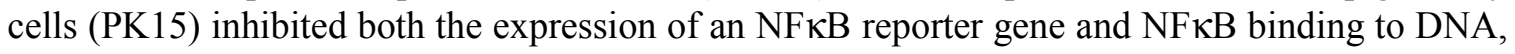
indicating that $\mathrm{A} 238 \mathrm{~L}$ had functional $\mathrm{I} \kappa \mathrm{B}$ activity[27]. Since the $\mathrm{NF} \kappa \mathrm{B}$ protein complex functions as a pleiotrophic transcription factor that modulates a variety of genes in cells of the immune system ( $\mathrm{T}$ cells, B cells, and monocyte/macrophages), a viral-encoded I $\mathrm{B}$ could conceivably 
TABLE 1

African Swine Fever Virus Genes with Predicted and/or Identified Functions in Critical Virus-Cell Interactions

\begin{tabular}{|c|c|c|c|c|}
\hline ASFV Genes & ORF & $\begin{array}{c}\text { Characteristics/ } \\
\text { Homology }\end{array}$ & Function & References \\
\hline \multirow[t]{4}{*}{ Structural proteins } & p30 & early; membrane & Attachment; VN & 14,15 \\
\hline & p54 & late; envelope & Internalization; VN & 15 \\
\hline & p72 & late; envelope & VN & 16,17 \\
\hline & $\mathrm{p} 12$ & early; envelope & Attachment & 18 \\
\hline \multirow{6}{*}{$\begin{array}{l}\text { Virulence/host range- } \\
\text { associated }\end{array}$} & NL & Early; HSV ICP 34.5 & Pig virulence & 19 \\
\hline & UK & Early; no homolog & Pig virulence & 20 \\
\hline & $9 G L$ & Late; yeast ERV1 & Pig virulence & 21 \\
\hline & TK & Early; thymidine kinase & $\begin{array}{l}\text { Growth in } \\
\text { macrophage; pig } \\
\text { virulence }\end{array}$ & 22 \\
\hline & MGF360 & Early; no homolog & $\begin{array}{l}\text { Macrophage host } \\
\text { range; pig } \\
\text { virulence }\end{array}$ & 23,24 \\
\hline & MGF530 & Early; no homolog & $\begin{array}{l}\text { Macrophage host } \\
\text { range; pig } \\
\text { virulence }\end{array}$ & 23,24 \\
\hline \multirow[t]{3}{*}{$\begin{array}{l}\text { Immune response } \\
\text { modulation }\end{array}$} & $5 E L$ & Early; ІкB & $\begin{array}{l}\text { Inhibition of } \\
\text { proinflammatory } \\
\text { cytokines }\end{array}$ & $25,26,27$ \\
\hline & 8-DR & Late; T-lymphocyte CD2 & $\begin{array}{l}\text { Cell-adhesion; T- } \\
\text { cell response }\end{array}$ & $28,29,30$ \\
\hline & $8 \mathrm{CR}$ & Late; C-type lectins & $\begin{array}{l}\text { Cell-adhesion; } \\
\text { signal } \\
\text { transduction; }\end{array}$ & 13,31 \\
\hline \multirow[t]{5}{*}{ Apoptosis regulation } & $5 \mathrm{HL}$ & Early to late; $\mathrm{Bcl}-2$ & Inhibition & 32,33 \\
\hline & $4 \mathrm{CL}$ & Late; IAP & $\begin{array}{l}\text { Inhibition / } \\
\text { caspase-3 binding }\end{array}$ & $34,35,36$ \\
\hline & $5 E L$ & Early; ІкB & $\begin{array}{l}\text { Inhibition / NFאB, } \\
\text { NFAT }\end{array}$ & 26,37 \\
\hline & MGF360 & Early; no homolog & Inhibition & 24 \\
\hline & MGF530 & Early; no homolog & Inhibition & 24 \\
\hline
\end{tabular}

play a highly significant role in counteracting an antiviral response in the ASFV-infected swine host. Indeed, data show that 5EL interacts with the RelA subunit of NFKB, where it is able to prevent binding of NFKB to target sequences and inhibit NFKB-dependent gene expression[27,42,43]. 5EL also provides a mechanism that enables ASFV to evade host defense systems by preventing the transcription of cellular NFAT transcription factor[25,44]. Given the central role of NFKB and NFAT in regulating the rapid expression of many genes encoding immunomodulatory proteins in monocytes and macrophages following activating stimuli, it is surprising that deletion of 5EL from the Malawi Lil-20/1 genome had no effect on disease onset, disease course, or viral virulence[26]. 


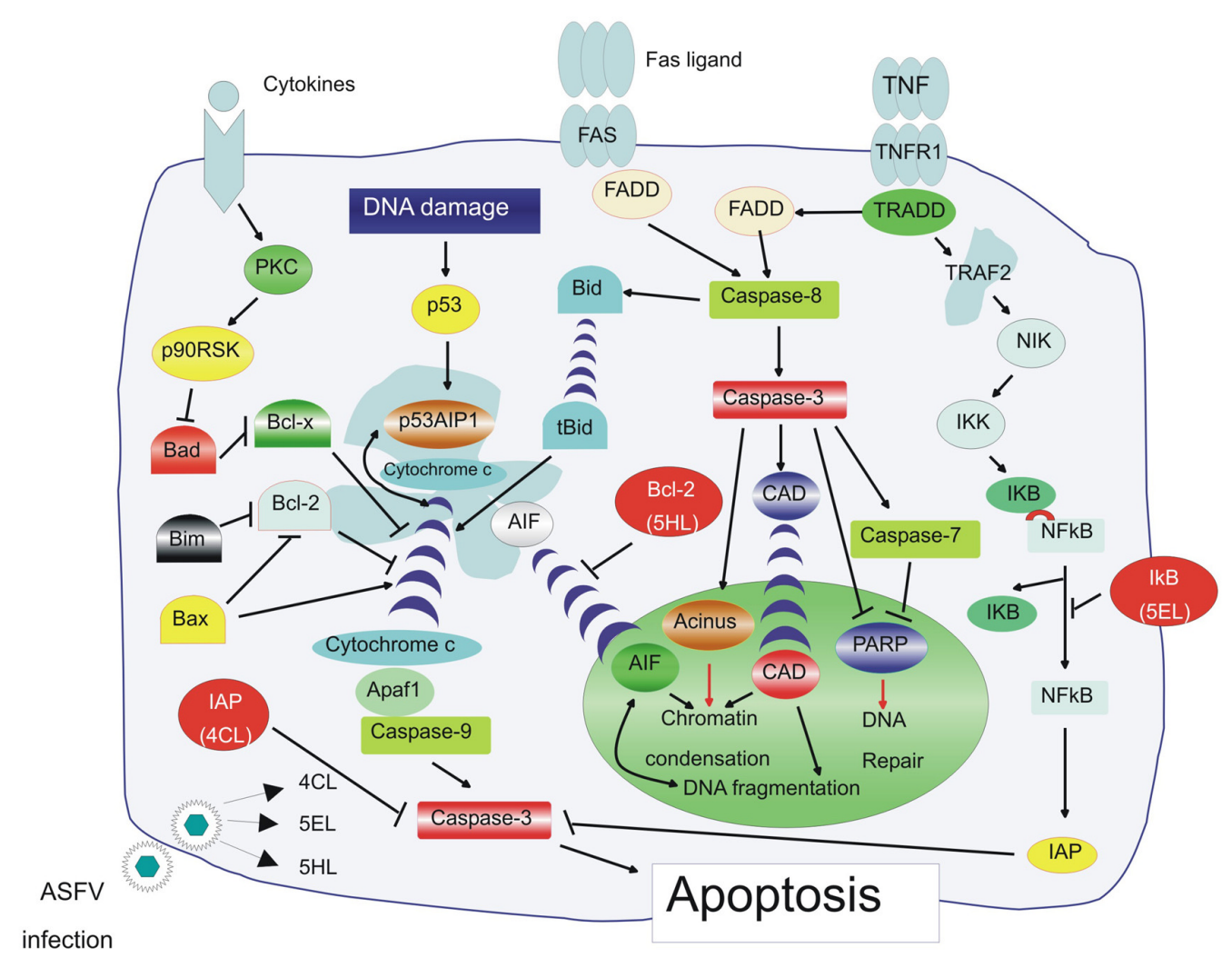

FIGURE 1. Viral-induced apoptosis in African swine fever virus infected macrophages.

\section{VIRAL-INDUCED APOPTOSIS IN ASFV-INFECTED MACROPHAGES}

Apoptosis is a common pathway of virus-induced cell death. A number of viruses have evolved antiapoptotic mechanisms to promote infected-cell survival, either to ensure efficient productive viral replication or to promote long-term survival of virus-infected cells (for a review, see 45).

Sequencing and genome analysis of complete ASFV genomes have led to the identification of several genes that are likely involved in the complex regulation of viral-induced apoptotic mechanisms in infected swine macrophages. Earlier, we described an ASFV gene, 5-HL, with a high degree of similarity to the proto-oncogene Bcl-2[33](Fig. 1). The gene encodes a protein of $18 \mathrm{kDa}(\mathrm{p} 21)$ that is present in infected porcine macrophages at both early and late times postinfection. The similarity of 5-HL to Bcl-2 suggested a role for it in cell maintenance during productive or persistent viral infection. Subsequent studies showed that 5-HL is a true functional viral member of the Bcl-2 gene family. The Bcl-2 family includes genes encoding proteins that can either inhibit apoptosis $\left(\mathrm{Bcl}-2, \mathrm{Bcl}-\mathrm{x}_{\mathrm{L}}\right)$ or promote programmed cell death (Bax, Bcl- $\mathrm{x}_{\mathrm{S}}$, Bak). The prototype of the family, the Bcl-2 gene, was discovered in 1985 by genetic analysis of a chromosomal translocation that is characteristic of human follicular lymphoma[46]. Many more members of the still growing family have been identified. The ASFV 5-HL protein product, p21, suppressed apoptotic cell death in the mammalian lymphoid cell line FL5.12[32], in HeLa and BSC-40 cells[47], in the human myeloid leukemia cell line K562[48], and in insect cells[49]. In addition to ASFV, viral members of the Bcl-2 gene family in gammaherpesviruses and adenoviruses have been described[50,51]. The E1B 19-kDa protein of adenovirus has been shown to prolong infected-cell survival by inhibiting apoptosis induced by adenovirus E1A protein, tumor necrosis factor alpha, and Fas antigen[52]. Similarly, ASFV 5-HL may suppress apoptosis 
in ASFV-infected cells, thus promoting the survival of host cells during productive and/or persistent infection of either the pig or tick host. Certainly, this gene is highly conserved and present in even highly cell-culture-adapted viruses[32]; unsuccessful attempts to delete it from the viral genomes of pathogenic isolates suggest that it is essential for replication in swine macrophages (J. G. Neilan, unpublished data). ASFV infection induces apoptosis in primary swine macrophages in vitro as early as $20 \mathrm{~h}$ postinfection, a time at which viral replication has already occurred in these cells[35]. Thus, it is possible that p21, which is expressed throughout the infection cycle, including early time points, transiently modulates infected-macrophage survival, allowing productive viral replication to occur. Cytopathological changes consistent with apoptotic cell death, including karyorrhexis and chromatin condensation, have been observed in mononuclear cells (lymphocytes and monocytes/macrophages) in tissues of pigs infected with highly virulent ASFV isolates[8,53,54]. Therefore, suppression of apoptosis may be of significance to aspects of viral pathogenesis, and virulence and p21 may mediate this effect. Additionally, because ASFV-swine monocyte/macrophage interactions result in either lytic or latent infection[55], p21 could conceivably have a role in promoting the survival of latently infected mononuclear cells.

An ORF in the ASFV genome similar to inhibitor of apoptosis genes (iap) has been identified in a pathogenic African isolate, Malawi Lil-20/1[35], and an avirulent cell-cultureadapted European virus, BA71V[13]. The Malawi gene, 4CL shares 91.5\% amino acid identity with the homologous gene $\mathrm{A} 224 \mathrm{~L}$ present in BA71V. Both $4 \mathrm{Cl}$ and $\mathrm{A} 224 \mathrm{~L}$ contain a single baculovirus IAP repeat motif (BIR motif). A224L has been shown to encode a 27-kDa late, structural protein[34]. Inhibitor of apoptosis genes were first described in baculoviruses, where they were shown to inhibit apoptosis of virus-infected cells[56]; later, human iap genes were identified and shown to inhibit apoptosis under in vitro assay conditions[57]. These genes encode proteins that contain one to three copies of IAP repeat motifs referred to as BIR motifs. The BIR motifs are involved in all known interactions between IAPs and other proteins, including binding to at least two members of the caspase family of cell death proteases, caspase- 3 and caspase- 7 . Human IAPs have been shown to prevent the proteolytic processing of procaspase- $3,-6$, and -7 by blocking the cytochrome c-induced activation of procaspase-9[58]. These IAP family proteins can also suppress apoptotic pathways by inhibiting active caspase-3 directly[59]. Recently, Nogal et al.[36] reported that ASFV A224L modulates the proteolytic processing of caspase-3 and the apoptosis which are induced in infected VERO cell cultures. Their findings showed that A224L interacts with the proteolytic fragment of caspase- 3 and inhibits the activity of this protease during viral infection. These data indicated a common mechanism of action for ASFV IAP and other IAP family members in inhibition of apoptotis. However, other studies revealed that deletion of 4CL from pathogenic ASFV isolate did not affect viral growth and apoptosis in macrophages or virulence in swine[35]. Therefore, the antiapoptotic function of this viral gene could be cell-type specific, or in the critical target cells other viral or cellular genes might complement its effect. Since iap genes have also been identified in the iridoviridae virus family[60], it is tempting to speculate that $4 \mathrm{CL}$ may be a host range gene involved in some aspect of infection in the arthropod host, O. porcinus.

In the acute stage, ASF is characterized by disseminated intravascular coagulation with multiple hemorrhages in all tissues and marked lymphopenia[61]. In experimentally infected pigs, Oura et al.[9] found that ASFV was predominantly localized in cells of the mononuclear phagocytic system and was not observed in endothelial cells in lymphoid tissue. Severe tissue destruction and cell depletion were seen in lymphoid tissues; the abundant lymphocyte death was caused by apoptosis. Although the mechanism of lymphocyte apoptosis induced by ASFVinfected macrophages was not defined, it is possible that release of TNF- $\alpha$ may contribute to the effect. In pigs infected with pathogenic European isolate E-75, enhanced TNF- $\alpha$ expression was detected which corresponded to the onset of clinical symptoms[37]. In addition, TNF- $\alpha$ containing supernatants from ASFV-infected macrophage cultures induced apoptosis in 
uninfected lymphocytes. These results suggested a relevant role for this cytokine in the pathogenesis of ASF. TNF is a type II membrane protein. Proteolysis of membrane-associated TNF, which is mediated by a membrane metallo-proteinase, produces a soluble form of this protein. Binding of this TNF to TNF-R leads to oligomerization of the receptor. Subsequently, the oligomerized TNF-R transmits signals to the cell that can result in the activation of NFKB and induction of apoptosis. Although ASFV does encode an IKB homolog gene, 5EL, which might be involved in the regulation of virus-induced TNF- $\alpha$ production, available data do not support directly this hypothesis. Deletion of 5EL from the pathogenic Malawi Lil-20/1 isolate did not alter the growth characteristics of the virus in swine macrophage cell cultures and virulence in pigs[26], suggesting that the gene has little or no effect on the regulation of apoptotic mechanisms in infected cells.

Variations in genome size and restriction fragment patterns are observed among different ASFV isolates. Like poxviruses, the diversity within the ASFV genome is localized primarily to the terminal genomic regions[62,63,64]. ASFV variable regions comprise the left $35-\mathrm{kb}$ and the right 15-kb ends of the genome, and contain at least five multigene families (MGFs): MGF100, MGF110, MGF300, MGF360, and MGF530[65,66,67,68,69]. Variations in these regions, including gene deletion events, are observed during ASFV adaptation to monkey cell lines[62,70]. Recently, MGF360 and MGF530 genes have been shown to have a significant role in ASFV macrophage host range; these genes function in promoting infected cell survival[24].

MGF360 and MGF530 genes do not show similarity to other genes or motifs in the current databases. Individual MGF genes are conserved among ASFV isolates ( 80 to $98 \%$ amino acid similarity) (G. F. Kutish, personal communication). Transcriptional analysis of MGF360 and MGF530 genes showed that these ORFs are transcribed early during ASFV infection[69,71, JG. Neilan, unpublished data], but translated proteins have not yet been identified or characterized. Alignments of predicted amino acid sequences of all MGF360 and MGF530 family members show three conserved regions at the amino terminus of these proteins[69]. These conserved regions may indicate common ancestral relationships among the MGF genes or roles for these genes in common or related pathways. The function of different multigene families in ASFV infection is unclear at present.

In our studies, removal of individual MGF530 genes or groups of MGF360 genes from the left variable region of a highly virulent ASFV isolate, $\operatorname{Pr} 4$, did not alter the viral growth in macrophage cell cultures. However, deletion of six MGF360 and two MGF530 ORFs from the left end of the $\mathrm{Pr} 4$ genome markedly reduced viral growth in primary macrophage cell cultures (Fig. 2); removal of two additional MGF360 genes resulted in no growth at all[24]. Cell viability studies and apoptosis assays revealed a significant reduction in survival time, and accelerated and increased apoptotic cell death in gene deletion mutant, $\Delta 35$-infected macrophage cell cultures (Fig. 2). Although little is known about MGF gene function during virus replication, it is tempting to speculate that gene dosage is a factor in replication in macrophages. Alternatively, specific MGF members may function and/or interact with each other in a yet-to-be-identified pathway(s). Given that macrophages are the primary target cells of ASFV in swine, it is likely that these genes are also of significance for viral pathogenesis and virulence in domestic swine. Most recently Neilan et al. reported that ASFV MGF360 and MGF530 genes as novel swine virulence determinants play important role in pig virulence[23]. Although swine virulence determinants and macrophage host range determinants differ phenotypically, they share four MGF genes, suggesting that they may have related functions in maintaining infected-cell survival in specific ASFV target cells, which are critical for a virulence phenotype in domestic pigs. These data indicate that ASFV MGF360 and MGF530 genes perform an essential macrophage host range function(s) that involves the promotion of infected cell survival. Reduced viral growth in macrophages together with increased early apoptotic death of virus-infected cells likely account for the attenuation of MGF gene deletion mutants in swine. 


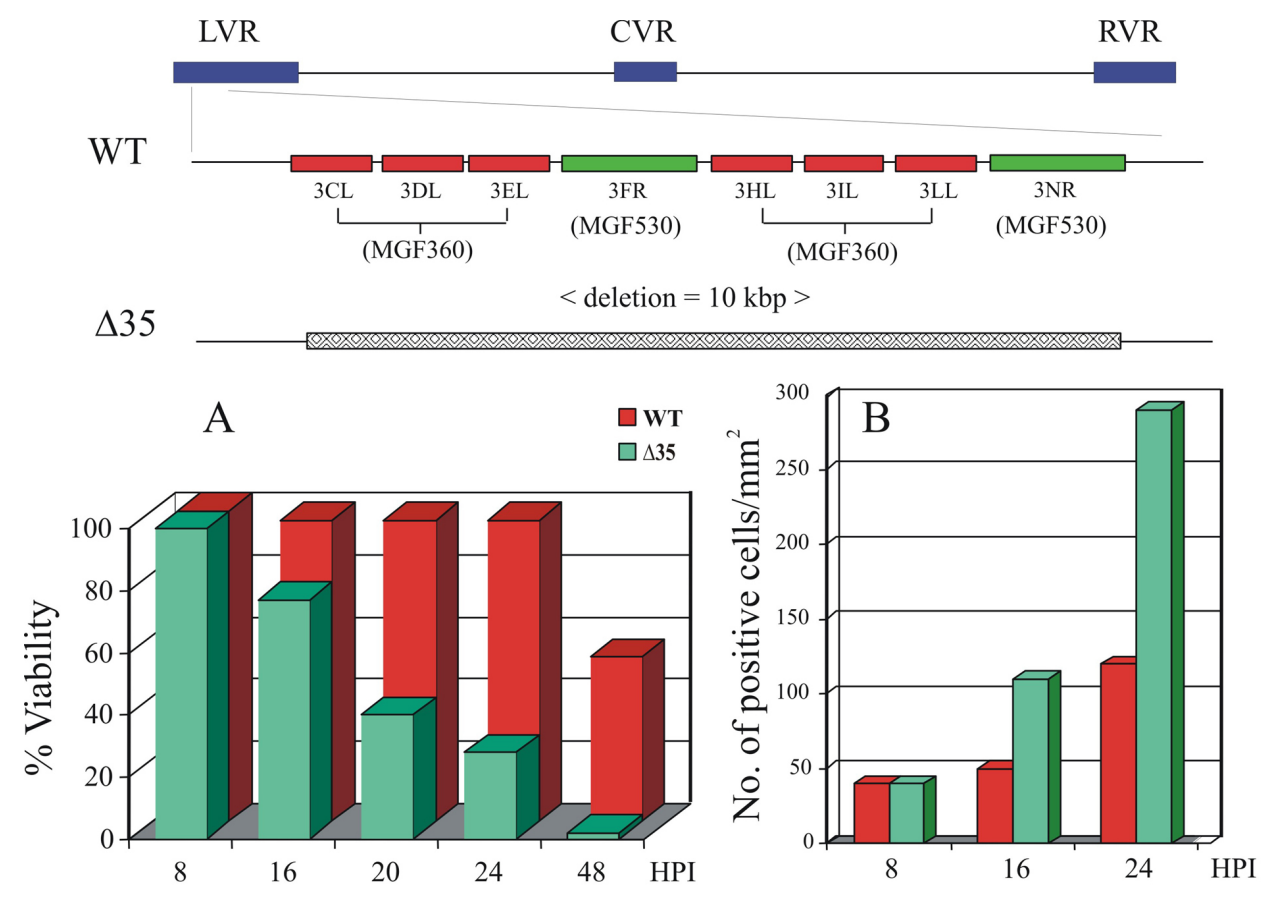

FIGURE 2. Cell viability (A) and TUNEL assays (B) in MGF360/530 gene deletion mutant, $\Delta 35$-infected porcine macrophage cell cultures. Cultures were infected $(\mathrm{MOI}=5)$ with wild-type $(\mathrm{WT})$ or $\Delta 35$ viruses, and examined by trypan blue exclusion viability assay and TUNEL assay at various times postinfection. Data indicate a significant reduction in survival time, and accelerated and increased apoptotic cell death in gene deletion mutant, $\Delta 35$-infected macrophages (Zsak et al., unpublished data).

\section{CONCLUSIONS}

Identification of critical virulence and host range genes of African swine fever virus revealed the complexity of virus-induced mechanisms in infected host. Although how these mostly novel viral genes mediate virulence, host range, and pathogenesis is not fully understood, it is likely that many of them perform essential function(s) during crucial ASFV-host interactions. Further identification and characterization of virulence and host range genes, and the mechanisms of their action, will permit engineering of viral strains attenuated for virulence and/or restricted host range as possible vaccine candidates.

\section{ACKNOWLEDGMENTS}

We thank Dr. D.L. Rock for his encouragement during the preparation of this manuscript.

\section{REFERENCES}

1. Dixon, L.K., Costa, J.V., Escribano, J.M., Rock, D.L., Vinuela, E., and Wilkinson, P. J. (2000) Family Asfarviridae. In Virus Taxonomy: $7^{\text {th }}$ Report of the International Committee on Taxonomy of Viruses. Regenmortel, M.H.V., Fauquet, C.M., Bishop, D.H.L., Carstens, E.B., Estes, M.K., and Wickner, S.M., Eds. Academic Press, San Diego, CA. pp. 159-165.

2. González, A., Talavera, A., Almendral, J.M., and Viñuela, E. (1986) Hairpin loop structure of African swine fever virus DNA. Nucleic Acids Res. 14, 6835-6844.

3. Ortin, J., Enjuanes, L., and Viñuela, E. (1979) Cross-links in African swine fever virus DNA. J. Virol. 31, 579-583.

4. Sogo, J.M., Almendral, J.M., Talavera, A., and Viñuela, E. (1984) Terminal and internal inverted repetitions in African swine fever virus DNA. Virology 133, 271-275. 
5. Costa, J.V. (1990) African swine fever virus. In Molecular Biology of Iridoviruses. Darai, G., Ed. Kluwer Academic Publishers, Norwell, MA. pp. 247-270.

6. Wilkinson, P.J. (1989) African swine fever virus. In Virus Infections of Porcines. Pensaert, M.B., Ed. Elsevier Science Publishers, Amsterdam. pp. 17-35.

7. Thomson, G.R. (1985) The epidemiology of African swine fever: the role of free-living hosts in Africa. Onderstepoort J. Vet. Res. 52, 201-209.

8. Oura, C.A., Powell, P.P., Anderson, E., and Parkhouse, R.M. (1998) The pathogenesis of African swine fever in the resistant bushpig. J. Gen. Virol. 79, 1439-1443.

9. Oura, C.A.L., Powell, P.P., and Parkhouse, R.M.E. (1998) African swine fever: a disease characterized by apoptosis. J. Gen. Virol. 79, 1427-1438.

10. Mebus, C.A. (1988). African swine fever. Adv. Virus. Res. 35, 251-269.

11. Vallee, I., Tait, S.W., and Powell, P.P. (2001) African swine fever virus infection of porcine aortic endothelial cells leads to inhibition of inflammatory responses, activation of the thrombotic state, and apoptosis. J. Virol. 75, 10372-10382.

12. Dixon, L.K., Twigg, S.R.F., Baylis, S.A., Vydelingum, S., Bristow, C., Hammond, J.M., and Smith, G.L. (1994) Nucleotide sequence of a $55 \mathrm{kbp}$ region from the right end of the genome of a pathogenic African swine fever virus isolate (Malawi LIL20/1). J. Gen. Virol. 75, 1655-1684.

13. Yáñez, R.J., Rodríguez, J.M., Nogal, M.L., Yuste, L., Enríquez, C., Rodriguez, J. F., and Viñuela, E. (1995) Analysis of the complete nucleotide sequence of African swine fever virus. Virology 208, 249-278.

14. Afonso, C.L., Alcaraz, C., Brun, A., Sussman, M.D., Onisk, D.V., Escribano, J. M., and Rock, D.L. (1992). Characterization of $\mathrm{p} 30$, a highly antigenic membrane and secreted protein of African swine fever virus. Virology 189, 368-373.

15. Gomez-Puertas, P., Rodríguez, F., Oviedo, J.M., Brun, A., Alonso, C., and Escribano, J.M. (1998) The African swine fever virus proteins p54 and p30 are involved in two distinct steps of virus attachment and both contribute to the antibody-mediated protective immune response. Virology 243, 461-471.

16. Borca, M.V., Irusta, P., Carrillo, C., Afonso, C.L., Burrage, T., and Rock, D.L. (1994) African swine fever virus structural protein $\mathrm{p} 72$ contains a conformational neutralizing epitope. Virology 201, 413-418.

17, Zsak, L., Onisk, D.V., Afonso, C.L., and Rock, D.L. (1993) Virulent African swine fever virus isolates are neutralized by swine immune serum and by monoclonal antibodies recognizing a $72-\mathrm{kDa}$ viral protein. Virology 196, 596-602.

18. Carrascosa, A.L., Sastre, I., and Viñuela, E. (1991) African swine fever virus attachment protein. J. Virol. 65, 22832289.

19. Zsak, L., Lu, Z., Kutish, G.F., Neilan, J.G., and Rock, D.L. (1996) An African swine fever virus virulenceassociated gene NL-S with similarity to the herpes simplex virus ICP34.5 gene. J. Virol. 70, 8865-8871.

20. Zsak, L., Caler, E., Lu, Z., Kutish, G.F., Neilan, J.G., and Rock, D.L. (1998) A nonessential African swine fever virus gene UK is a significant virulence determinant in domestic swine. J. Virol. 72, 1028-1035.

21. Lewis, T., Zsak, L., Burrage, T.G., Lu, Z., Kutish, G.F., Neilan, J.G., and Rock, D.L. (2000) An African swine fever virus ERV1-ALR homologue, 9GL, affects virion maturation and viral growth in macrophages and viral virulence in swine. J. Virol. 74, 1275-1285.

22. Moore, D.M., Zsak, L., Neilan, J.G., Lu, Z., and Rock, D.L. (1998) The African swine fever virus thymidine kinase gene is required for efficient replication in swine macrophages and for virulence in swine. J. Virol. 72 , 10310-10315.

23. Neilan, J.G., Zsak, L., Lu, Z., Kutish, G.F., Afonso, C.L., and Rock, D. L. (2002) A novel swine virulence determinant in the left variable region of the African swine fever virus genome. J. Virol. 76, 3095-3104.

24. Zsak, L., Lu, Z., Burrage, T.G., Neilan, J.G., Kutish, G.F., Moore, D.M., and Rock, D.L. (2001) African swine fever virus multigene family 360 and 530 genes are novel macrophage host range determinants. $J$. Virol. 75, 3066-3076.

25. Miskin, J.E., Abrams, C.C., Goatley, L.C., and Dixon, L.K. (1998) A viral mechanism for inhibition of the cellular phosphatase calcineurin. Science 281, 562-565.

26. Neilan, J.G., Lu, Z., Kutish, G.F., Zsak, L., Lewis, T.L., and Rock, D.L. (1997) A conserved African swine fever virus IkB homolog, $5 \mathrm{EL}$, is nonessential for growth in vitro and virulence in domestic pigs. Virology 235, 377-385.

27. Powell, P.P., Dixon, L.K., and Parkhouse, R.M.E. (1996) An IkB homolog encoded by African swine fever virus provides a novel mechanism for downregulation of proinflammatory cytokine responses in host macrophages. J. Virol. 70, 8527-8533.

28. Borca, M.V., Carrillo, C., Zsak, L., Laegreid, W.W., Kutish, G.F., Neilan, J.G., Burrage, T.G., and Rock, D.L. (1998) Deletion of a CD2-like gene, 8-DR, from African swine fever virus affects viral infection in domestic swine. J. Virol. 72, 2881-2889.

29. Borca, M.V., Kutish, G.F., Afonso, C.L., Irusta, P., Carrillo, C., Brun, A., Sussman, M., and Rock, D.L. (1994) An African swine fever virus gene with similarity to the T-lymphocyte surface antigen CD2 mediates hemadsorption. Virology 199, 463-468. 
30. Rodríguez, J.M., Yáñez, R.J., Almazán, F., Viñuela, E., and Rodriguez, J.F. (1993) African swine fever virus encodes a CD2 homolog responsible for the adhesion of erythrocytes to infected cells. J. Virol. 67, 53125320 .

31. Neilan, J.G., Borca, M.V., Lu, Z., Kutish, G.F., Kleiboeker, S.B., Carrillo, C., Zsak, L., and Rock, D.L. (1999) An African swine fever virus ORF with similarity to C-type lectins is non-essential for growth in swine macrophages in vitro and for virus virulence in domestic swine. J. Gen. Virol. 80, 2693-2697.

32. Afonso, C.L., Neilan, J.G., Kutish, G.F., and Rock, D.L. (1996) An African swine fever virus bcl-2 homolog, 5-HL, suppresses apoptotic cell death. J. Virol. 70, 4858-4863.

33. Neilan, J.G., Lu, Z., Afonso, C.L., Kutish, G.F., Sussman, M.D., and Rock, D.L. (1993) An African swine fever virus gene with similarity to the proto-oncogene bcl-2 and the Epstein-Barr virus gene BHRF1. J. Virol. 67, 4391-4394.

34. Chacon, M.R., Almazán, F., Nogal, M.L., Viñuela, E., and Rodríguez, J.F. (1995) The African swine fever virus IAP homolog is a late structural polypeptide. Virology 214, 670-674.

35. Neilan, J.G., Lu, Z., Kutish, G.F., Zsak, L., Burrage, T.G., Borca, M.V., Carrillo, C., and Rock, D.L. (1997) A BIR motif containing gene of African swine fever virus, $4 \mathrm{CL}$, is nonessential for growth in vitro and viral virulence. Virology 230, 252-264.

36. Nogal, M.L., de Buitrago, G.G., Rodríguez, C., Cubelos, B., Carrascosa, A.L., Salas, M.L., and Revilla, Y. (2001) African swine fever virus IAP homologue inhibits caspase activation and promotes cell survival in mammalian cells. J. Virol. 75, 2535-2543.

37. Gomez del Moral, M., Ortuno, E., Fernandez-Zapatero, P., Alonso, F., Alonso, C., Ezquerra, A., and Dominguez, J. (1999) African swine fever virus infection induces tumor necrosis factor alpha production: implications in pathogenesis. J. Virol. 73, 2173-2180.

38. Carrascosa, A.L., Bustos, M.J., Galindo, I., and Viñuela, E. (1999) Virus-specific cell receptors are necessary, but not sufficient, to confer cell susceptibility to African swine fever virus. Arch. Virol. 144, 1309-1321.

39. Chou, J., Kern, E.R., Whitley, R.J., and Roizman, B. (1990) Mapping of herpes simplex virus-1 neurovirulence to g134.5, a gene nonessential for growth in culture. Science 250, 1262-1266.

40. Afonso, C.L., Zsak, L., Carrillo, C., Borca, M.V., and Rock, D.L. (1998) African swine fever virus NL gene is not required for virus virulence. J. Gen. Virol. 79, 2543-2547.

41. Spriggs, M.K. (1994) Cytokine and cytokine receptor genes "captured" by viruses. Curr. Opin. Immunol. 6, 526-529.

42. Revilla, Y., Callejo, M., Rodríguez, J.M., Culebras, E., Nogal, M.L., Salas, M.L., Viñuela, E., and Fresno, M. (1998) Inhibition of nuclear factor kappaB activation by a virus-encoded IkappaB-like protein. J. Biol. Chem. 273, 5405-5411.

43. Tait, S.W., Reid, E.B., Greaves, D.R., Wileman, T.E., and Powell, P.P. (2000) Mechanism of inactivation of NF-kappa B by a viral homologue of I-kappa B alpha. Signal-induced release of I-kappa B alpha results in binding of the viral homologue to NF-kappa B. J. Biol. Chem. 275, 34656-34664.

44. Miskin, J.E., Abrams, C.C., and Dixon, L.K. (2000) African swine fever virus protein A238L interacts with the cellular phosphatase calcineurin via a binding domain similar to that of NFAT. J. Virol. 74, 9412-9420.

45. Razvi, E.S., and Welsh, R.M. (1995) Apoptosis in viral infections. Adv. Virus. Res. 45, 1-60.

46. Bakhshi, A., Jensen, J.P., Goldman, P., Wright, J.J., McBride, O.W., Epstein, A.L., and Korsmeyer, S.J. (1985) Cloning the chromosomal breakpoint of $\mathrm{t}(14 ; 18)$ human lymphomas: clustering around $\mathrm{JH}$ on chromosome 14 and near a transcriptional unit on 18. Cell 41, 899-906.

47. Brun, A., Rivas, C., Esteban, M., Escribano, J.M., and Alonso, C. (1996) African swine fever virus gene A179L, a viral homologue of bcl-2, protects cells from programmed cell death. Virology 225, 227-230.

48. Revilla, Y., Cebrian, A., Baixeras, E., Martinez, C., Viñuela, E., and Salas, M.L. (1997) Inhibition of apoptosis by the African swine fever virus Bcl-2 homologue: role of the BH1 domain. Virology 228, 400-404.

49. Brun, A., Rodriguez, F., Escribano, J.M., and Alonso, C. (1998) Functionality and cell anchorage dependence of the African swine fever virus gene A179L, a viral bcl-2 homolog, in insect cells. J. Virol. 72, 10227-10233.

50. Chiou, S.K., Tseng, C.C., Rao, L., and White, E. (1994) Functional complementation of the adenovirus E1B 19-kilodalton protein with Bcl-2 in the inhibition of apoptosis in infected cells. J. Virol. 68, 6553-6566.

51. Marchini, A., Tomkinson, B., Cohen, J.I., and Kieff, E. (1991) BHRF1, the Epstein-Barr virus gene with homology to $\mathrm{Bc} 12$, is dispensable for B-lymphocyte transformation and virus replication. J. Virol. 65, 59916000 .

52. White, E., Sabbatini, P., Debbas, M., Wold, W. S., Kusher, D.I., and Gooding, L.R. (1992) The 19-kilodalton adenovirus E1B transforming protein inhibits programmed cell death and prevents cytolysis by tumor necrosis factor alpha. Mol. Cell. Biol. 12, 2570-2580.

53. Gomez-Villamandos, J.C., Hervas, J., Mendez, A., Carrasco, L., de las Mulas, J.M., Villeda, C.J., Wilkinson, P.J., and Sierra, M.A. (1995) Experimental African swine fever: apoptosis of lymphocytes and virus replication in other cells. J. Gen. Virol. 76, 2399-2405.

54. Ramiro-Ibanez, F., Ortega, A., Brun, A., Escribano, J.M., and Alonso, C. (1996). Apoptosis: a mechanism of cell killing and lymphoid organ impairment during acute African swine fever virus infection. J. Gen. Virol. 77, 2209-2219. 
55. Carrillo, C., Borca, M.V., Afonso, C.L., Onisk, D.V., and Rock, D.L. (1994) Long-term persistent infection of swine monocytes/macrophages with African swine fever virus. J. Virol. 68, 580-583.

56. Birnbaum, M.J., Clem, R.J., and Miller, L.K. (1994) An apoptosis-inhibiting gene from a nuclear polyhedrosis virus encoding a polypeptide with Cys/His sequence motifs. J. Virol. 68, 2521-2528.

57. Liston, P., Roy, N., Tamai, K., Lefebvre, C., Baird, S., Cherton-Horvat, G., Farahani, R., McLean, M., Ikeda, J. E., MacKenzie, A., and Korneluk, R. G. (1996) Suppression of apoptosis in mammalian cells by NAIP and a related family of IAP genes. Nature 379, 349-353.

58. Stennicke, H.R., Jurgensmeier, J.M., Shin, H., Deveraux, Q., Wolf, B.B., Yang, X., Zhou, Q., Ellerby, H.M., Ellerby, L.M., Bredesen, D., Green, D.R., Reed, J.C., Froelich, C.J., and Salvesen, G.S. (1998) Pro-caspase-3 is a major physiologic target of caspase-8. J. Biol. Chem. 273, 27084-27090.

59. Deveraux, Q.L., Roy, N., Stennicke, H.R., Van Arsdale, T., Zhou, Q., Srinivasula, S.M., Alnemri, E.S., Salvesen, G.S., and Reed, J.C. (1998) IAPs block apoptotic events induced by caspase- 8 and cytochrome c by direct inhibition of distinct caspases. Embo J. 17, 2215-2223.

60. Handermann, M., Schnitzler, P., Rosen-Wolff, A., Raab, K., Sonntag, K.C., and Darai, G. (1992) Identification and mapping of origins of DNA replication within the DNA sequences of the genome of insect iridescent virus type 6. Virus Genes 6, 19-32.

61. Sanchez-Vizcaino, J.M., Slauson, D.O., Ruiz-Gonzalvo, F., and Valero, F. (1981) Lymphocyte function and cell-mediated immunity in pigs with experimentally induced African swine fever. Am. J. Vet. Res. 42, 13351341 .

62. Blasco, R., Agüero, M., Almendral, J.M., and Viñuela, E. (1989) Variable and constant regions in African swine fever virus DNA. Virology 168, 330-338.

63. Dixon, L.K., and Wilkinson, P.J. (1988) Genetic diversity of African swine fever virus isolates from soft ticks (Ornithodoros moubata) inhabiting warthog burrows in Zambia. J. Gen. Virol. 69, 2981-2993.

64. Sumption, K.J., Hutchings, G.H., Wilkinson, P.J., and Dixon, L.K. (1990) Variable regions on the genome of Malawi isolates of African swine fever virus. J. Gen. Virol. 71, 2331-2340.

65. Almendral, J.M., Almazán, F., Blasco, R., and Viñuela, E. (1990) Multigene families in African swine fever virus: Family 110. J. Virol. 64, 2064-2072.

66. De la Vega, I., Viñuela, E., and Blasco, R. (1990) Genetic variation and multigene families in African swine fever virus. Virology 179, 234-246.

67. González, A., Calvo, V., Almazan, F., Almendral, J.M., Ramirez, J.C., de la Vega, I., Blasco, R., and Viñuela, E. (1990) Multigene families in African swine fever virus: Family 360. J. Virol. 64, 2073-2081.

68. Vydelingum, S., Baylis, S.A., Bristow, C., Smith, G.L., and Dixon, L.K. (1993) Duplicated genes within the variable right end of the genome of a pathogenic isolate of African swine fever virus. J. Gen. Virol. 74, 21252130.

69. Yozawa, T., Kutish, G.F., Afonso, C.L., Lu, Z., and Rock, D.L. (1994). Two novel multigene families, 530 and 300, in the terminal variable regions of African swine fever virus genome. Virology 202, 997-1002.

70. Tabarés, E., Olivares, I., Santurde, G., Garcia, M.J., Martin, E., and Carnero, M. E. (1987) African swine fever virus DNA: deletions and additions during adaptation to growth in monkey kidney cells. Arch. Virol. 97, 333-346.

71. Rodríguez, J.M., Yáñez, R.J., Pan, R., Rodríguez, J.F., Salas, M.L., and Viñuela, E. (1994) Multigene families in African swine fever virus: Family 505. J. Virol. 68, 2746-2751.

This article should be referenced as follows:

Zsak, L. and Neilan, J.G. (2002) Regulation of apoptosis in African swine fever virus-infected macrophages. TheScientificWorldJOURNAL 2, 1186-1195.

\section{Handling Editor:}

David M. Knipe, Principal Editor for Virology — a domain of TheScientificWorldJOURNAL. 

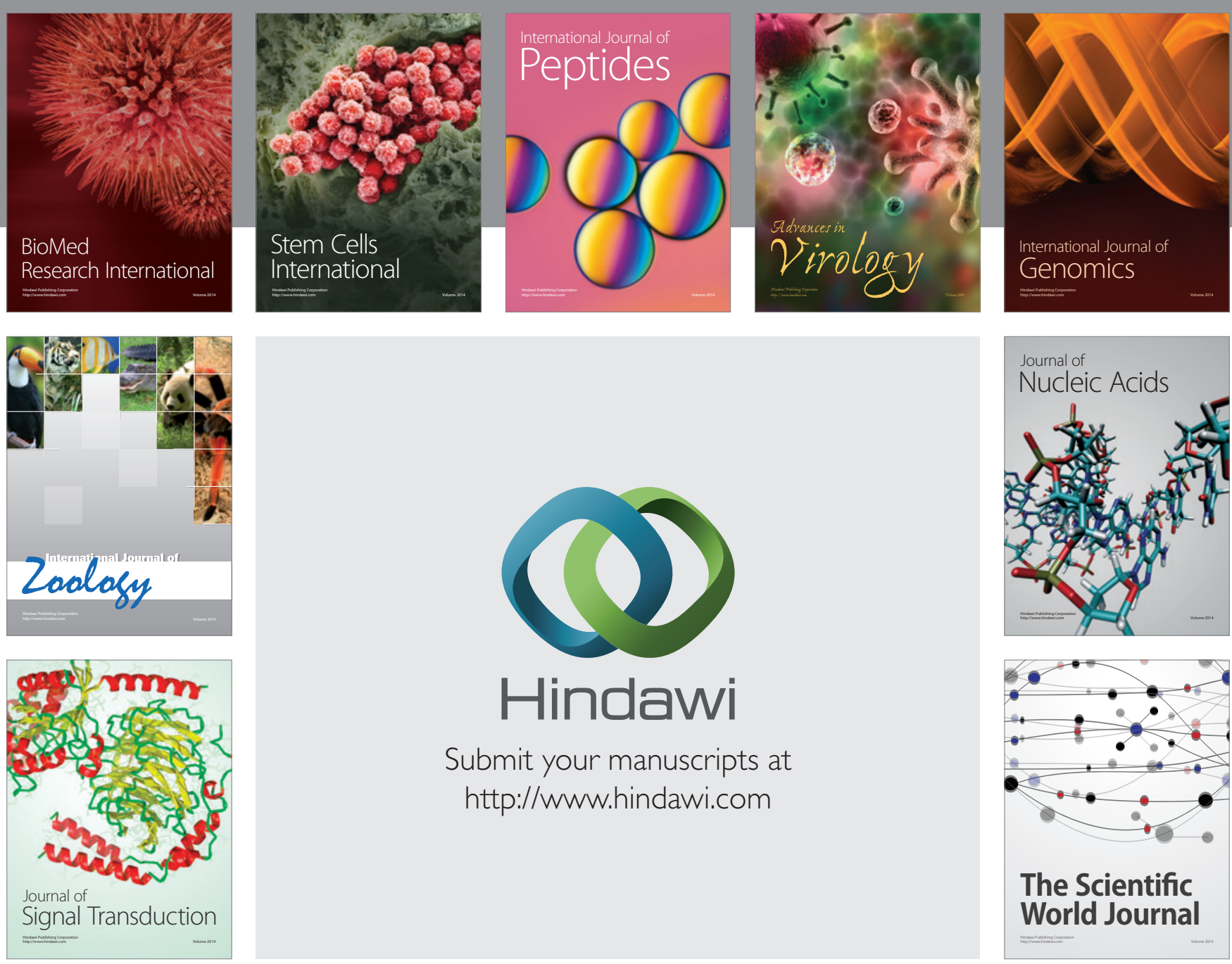

Submit your manuscripts at

http://www.hindawi.com
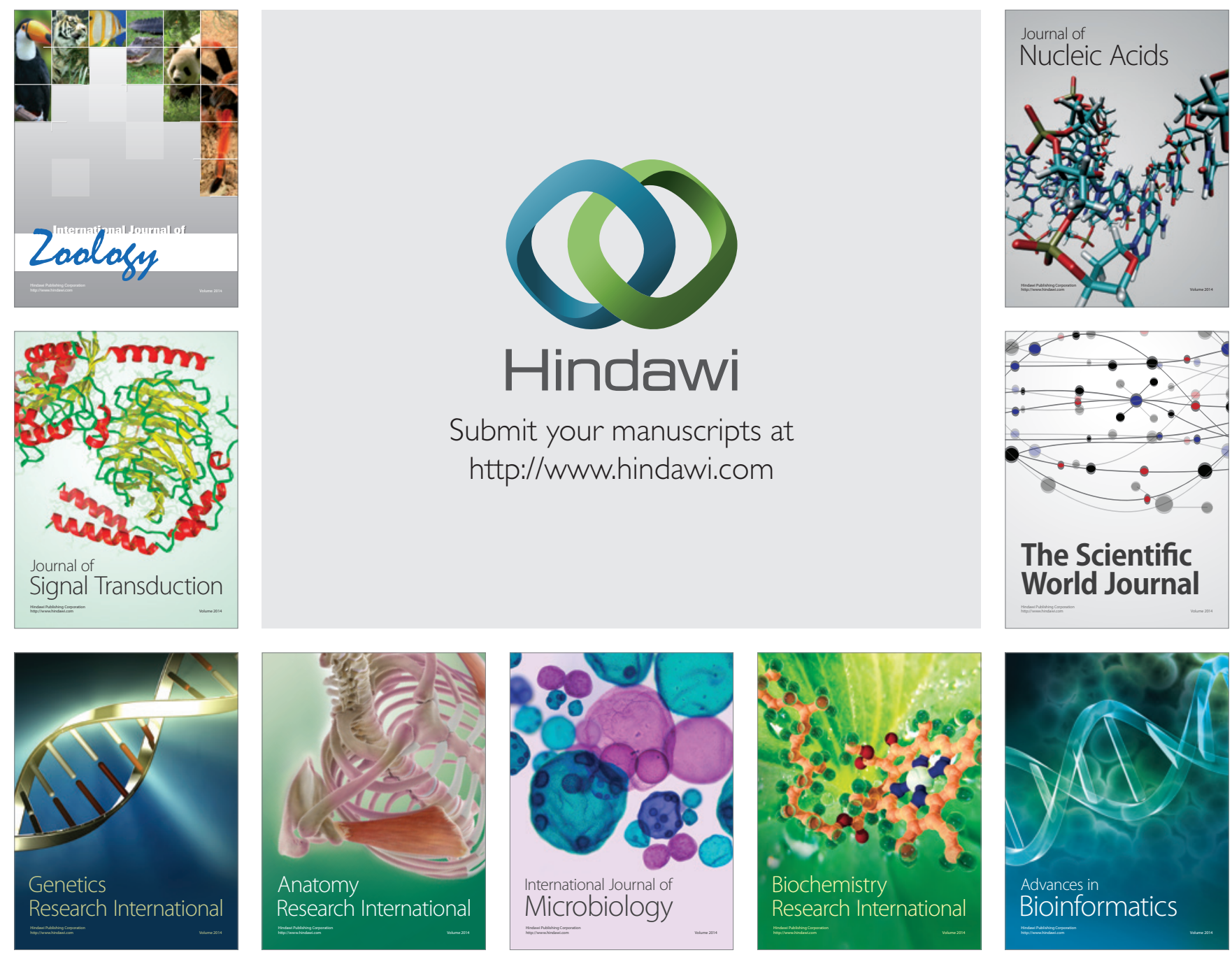

The Scientific World Journal
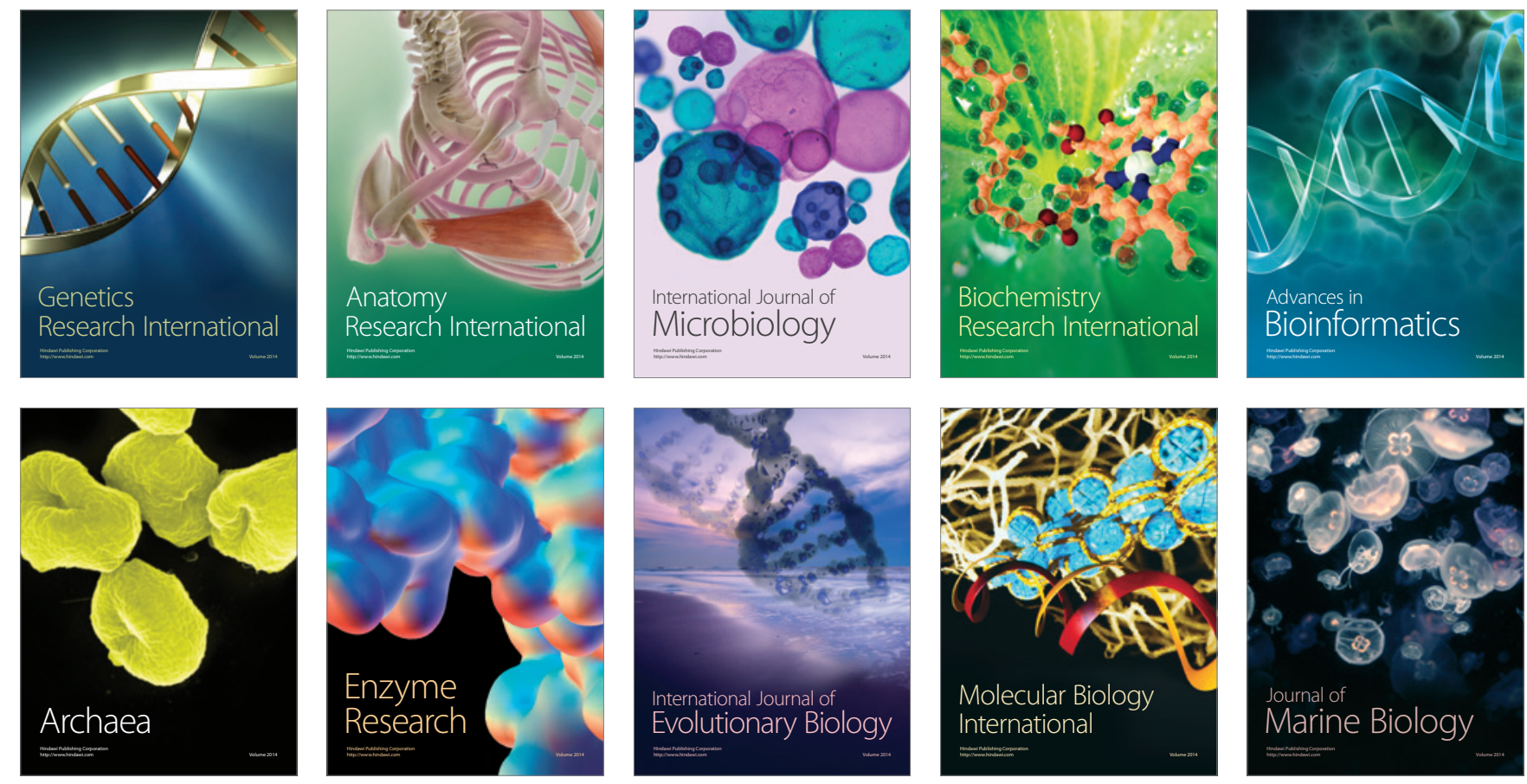